\title{
DEVOÇÕES ATLÂNTICAS: \\ A CONSTRUÇÃO DA IDENTIDADE SOCIAL E RELIGIOSA DE CATIVOS E LIBERTOS NA BAHIA COLONIAL.
}

REGINALDO, Lucilene. Os rosários dos angolas - irmandades de africanos e crioulos na Bahia setecentista. São Paulo: Alameda, 2011. 416p.

$O$

surgimento das associações confraternais remonta à Antiguidade tardia, mas foi diante dos desafios impostos à Igreja Católica, no início da época moderna, que sua propagação avançou a passos largos. Ao conjugar consistência teórica e doutrinal a um enorme sucesso popular, o movimento protestante pôs em xeque a unidade religiosa da Europa e excluiu de maneira irreversível o domínio da Igreja sobre vastos territórios do norte europeu. O saldo deste confronto, que fez do campo religioso uma província da esfera política, deu origem à formação dos estados confessionais e levou a Igreja a investir na sua aproximação com os laicos, instigandoos a uma participação mais ativa na vida religiosa através da filiação às irmandades.

Organizadas a volta de um orago protetor, as irmandades desempenharam, no período moderno, um papel importantíssimo na preservação dos preceitos e valores do catolicismo entre os leigos. Contribuíram tanto para valorizar o clero e os sacramentos da Igreja - por meio dos ofícios litúrgicos e dos ritos de passagem que orientavam a vida de cada crente -, quanto para preservar o culto aos santos e o calendário religioso romano, por meio das festas em sua celebração. Na qualidade de entidades de ajuda mútua, que uniam gente de um mesmo estatuto social, garantiam ao confrade apoio em casos de doença, morte ou invalidez, amenizando o impacto da ausência familiar ou vicinal quando o sujeito encontravase longe do lugar de residência.

Em Portugal, as funções religiosa e assistencial das irmandades somaram-se às demandas sociais e civis da sociedade, à medida que a expansão ultramarina e a política de colonização lusa estimulavam as correntes migratórias e o tráfico de escravos. A combinação entre propósi- 
tos espirituais distintos e interesses temporais peculiares diversificou o perfil das associações confraternais, formando, pelo menos, quatro tipos de irmandades: as penitentes, as profissionais, as assistenciais gerais e as assistenciais específicas. ${ }^{1}$

Assim, a Santa Casa da Misericórdia, confraria régia sustentada pela nata da fidalguia portuguesa, punha em prática as obras corporais da misericórdia, prestando atendimento aos pobres envergonhados, presos, doentes, órfãos e alienados; a Confraria da Santíssima Trindade agenciava o resgate dos cristãos cativos nas mãos dos infiéis; as irmandades de São Jorge, São José e São Crispim, formadas a partir das corporações de ofício, davam assistência aos oficiais mecânicos; e as irmandades de São Benedito e de Nossa Senhora do Rosário dos Pretos tinham como objetivo último a alforria dos irmãos escravos.

Terceira invocação mais frequente no conjunto das irmandades portuguesas do século XVIII, Nossa Senhora do Rosário compôs, ao lado das Almas do Purgatório e do Santíssimo Sacramento, a tríade devocional mais popular em Portugal no período moderno. Estimuladas pela Igreja na se-

1 Maria Alexandre Lousada, "Espaço urbano, sociabilidades e confrarias. Lisboa nos finais do Antigo Regime", in Actas do Colóquio Internacional Piedade Popular. Sociabilidades, representações, espiritualidades (Lisboa: Terramar, 1999), pp. 537-58. quência do Concílio de Trento, ${ }^{2}$ essas devoções contribuíram para reafirmar a geografia católica do sagrado, o mistério da transubstanciação na Eucaristia e a hiperdulia mariana, tão duramente atacados pelos reformadores protestantes.

A defesa dos sacramentos, dogmas e figuras santas, levou a Igreja a pôr em relevo personagens e linguagens que aproximassem os fiéis do culto católico. Os passos de Jesus na Via Sacra, a consternação de Maria aos pés do filho crucificado, a ressurreição de Cristo e ascensão da Virgem aos céus, inspiraram sermões e autos teatrais. O rosário, fórmula recitativa desenvolvida pelos monges medievais para que a massa iletrada de fiéis, incapazes de ler o saltério, acompanhasse as orações, foi reabilitado. O estímulo à repetição rítmica do terço, em honra aos quinze mistérios gozosos, dolorosos e gloriosos da vida de Jesus, impulsionou a devoção popular a Nossa Senhora do Rosário e a organização de irmandades sob sua proteção.

A fé no poder medianeiro desta invocação da Virgem foi muitíssimo reforçada com o triunfo da armada cristã sobre a esquadra turca, na batalha naval de Lepanto, em 7 de outubro de 1571. Conta-se que a improvável derrota otomana ocorreu após

\footnotetext{
2 Pedro Penteado, "Confrarias portuguesas da Época Moderna", Revista Lusitânia Sacra, 2a ${ }^{a}$ série, n. 7I (1995), p.24
} 
a realização, neste dia, de uma procissão do rosário, na Praça de São Pedro, em Roma, para propiciar a vitória cristã. $\mathrm{O}$ feito permitiu que centenas de cristãos escravizados fossem libertados e criou, no circuito de crenças da época moderna, uma associação entre a Virgem do Rosário e a libertação do cativeiro.

Transformada em um dos grandes baluartes da reforma de Trento, a Virgem Maria incrustou-se na piedade popular lusa e serviu de esteio à evangelização dos povos colonizados pela Coroa. No continente africano e na América portuguesa, tal como na metrópole, cativos ou libertos, oriundos da África Central ou descendentes de nativos desta região, reuniram-se em irmandades sob a proteção de Nossa Senhora do Rosário. A identificação dos negros com esta invocação da Virgem relacionou-se, é claro, à experiência da escravidão. Mas também a concepções cristãs africanizadas, produzidas em resposta ao processo de catequização empreendido por missionários capuchinhos e jesuítas, no Congo e em Angola, no século XVI, como explica Lucilene Reginaldo na obra aqui resenhada (p. 69).

Resultado de sua tese doutoramento, defendida na Universidade Estadual de Campinas, em 2005, Os rosários dos angolas traz uma reflexão original sobre as identidades negras na Bahia colonial e seu papel na formação da religiosidade popular "baiana". A autora lança mão de uma abordagem inovadora ao tratar as associações confraternais criadas por escravos e libertos numa perspectiva atlântica, isto é, inseridas no quadro do império ultramarino português. Para fazer jus a este enfoque, Lucilene realizou vasta pesquisa documental em arquivos e bibliotecas de Portugal, Brasil e Angola, onde reuniu fontes diversas: civis, eclesiásticas, devocionais, cartoriais e administrativas.

Composto de cinco capítulos, o estudo mantém um diálogo instigante com a historiografia sobre a escravidão no mundo atlântico e apresenta conclusão original. Com base em provas empíricas irrefutáveis, a autora relativiza as interpretações consagradas de Nina Rodrigues, Pierre Verger e outros que, centrados na observação etnográfica dos candomblés soteropolitanos tradicionais e no tráfico dos escravos no século XIX, defenderam a supremacia dos grupos sudaneses na formação cultural da Bahia de antanho (p. 269, 270 e 297).

Ao propor a análise das irmandades de negros, considerando o estatuto social e a procedência geográfica de seus membros, a professora da Unicamp identificou o predomínio dos negros angolas na liderança das irmandades do Rosário. O "privilégio étnico" manteve-se mesmo quando o tráfico de escravos para a Bahia passou a privilegiar os escravos oriundos da Costa da Mina, nos sé- 
culos XVIII e XIX. Segundo a pesquisadora, a evidência demonstra que a experiência dos negros com o catolicismo, na África Centro-Ocidental, sobreviveu à diáspora e estimulou a formação de associações religiosas. Para Reginaldo, se os angolas foram os primeiros a se congregar em irmandades na Bahia, foi porque percebiam que o espaço das organizações confraternais era-lhes útil para vencer os desafios do cotidiano impostos pela escravidão e não apenas porque constituíram as primeiras grandes levas de africanos a chegar com o tráfico negreiro (pp. 240-41).

Para demonstrar sua tese, Lucilene recupera, no primeiro capítulo, o movimento de expansão do catolicismo na África Centro-Ocidental, iniciado em fins do século XV, e analisa o papel desempenhado pela religião como mediadora na aproximação entre portugueses e africanos. Esclarece que a chegada do homem branco por mar foi interpretada de acordo com a cosmovisão dos povos dessa região: os portugueses foram identificados como espíritos retornados do mundo dos mortos e, por conseguinte, conhecedores de mistérios e segredos que faziam de sua religião a mais poderosa dentre todas.

A expectativa de obter vantagens temporais e espirituais com as cerimônias do catolicismo levou, inicialmente, as elites do Congo a monopolizarem o batismo e a impedirem o acesso da população aos demais ritos da nova religião. Mas no século XVI, ressalta a autora, a insistência dos soberanos locais para a criação de uma diocese do Congo e Angola, desmembrada do bispado de São Tomé, confirmava seu interesse na formação de um clero nativo, pois assim teriam livre acesso aos ritos e símbolos cristãos sem a mediação dos portugueses.

As cerimônias do catolicismo tornaram-se, assim, suportes de legitimação da ordem política nos reinos da região. Conta Reginaldo que, no século XIX, quando o rei do Congo, D. Aleixo I, recebeu o trono, queixou-se ao governador de Angola, Manoel de Almeida e Vasconcelos, de não ter padre que o coroasse, recordando-lhe que a presença do sacerdote era indispensável para que fosse investido do poder inerente à função.

A crença nos benefícios trazidos com a conversão ao catolicismo não implicou, porém, na adoção integral de todos os preceitos e sacramentos da Igreja pelos grupos bantos. Segundo a historiadora, o caráter monogâmico e indissolúvel do matrimônio provocou, por exemplo, alta rejeição entre os bakongos, ao contrário do batismo, tão valorizado pela elite conguense. Apesar de seus esforços, jesuítas e capuchinhos foram incapazes de apagar do repertório de práticas religiosas certas cerimônias, 
como os cantos fúnebres (entambes) entoados em quimbundo pelos escravos dos defuntos. A despeito destes fracassos, os missionários foram muito bem-sucedidos na disseminação de certas devoções, como a da Virgem do Rosário.

Lucilene Reginaldo localizou pelo menos duas irmandades desta invocação em Angola, na época moderna. Uma em Matamba, no interior, e outra em Luanda, o maior centro difusor do catolicismo na África Central (p.59). A ausência de maiores referências sobre a primeira impediu-a de qualquer digressão sobre sua composição e duração. Mas os dados recolhidos sobre a segunda associação religiosa informam que era integrada por negros cativos e forros, que sua função teve início em 1628, por iniciativa do bispo, e que se manteve ativa até, pelo menos, 1744.

Segundo a historiadora, tal como as associações confraternais surgidas nas demais regiões do mundo atlântico português, a formação da Irmandade do Rosário de Luanda pautouse por critérios hierárquicos de cor, de origem social e de procedência geográfica, ou seja, seguindo "a lógica de exclusão e classificação dos povos convertidos" (p. 62). Neste circuito, a devoção à Virgem do Rosário nasceu entre os negros vinculada às marcas da "conversão e do cativeiro" (p. 63).

Em Portugal, informa a autora, a
Irmandade do Rosário dos Homens Pretos da Santíssima Trindade, assim como outras irmandades de negros, eram espaços importantes de proteção e apoio jurídicos para os irmãos escravos e libertos. Fosse para garantir-lhes a liberdade, fosse para tentar resgatá-los, impedindo que partissem para conquistas do Reino contra a própria vontade.

$\mathrm{Na}$ Bahia, as primeiras irmandades negras com a invocação da Virgem do Rosário surgiram no século XVII, tal como a de Luanda e a do Rosário dos Pretos, no Convento do Salvador, em Lisboa. Ao longo da centúria seguinte, tanto em Portugal quanto na América lusa, as irmandades do Rosário compostas de escravos e libertos se multiplicaram e predominaram numericamente, se comparadas com as confrarias de outros santos negros, como demonstra Lucilene Reginaldo no segundo e terceiro capítulos da obra.

De acordo com a historiadora, no século XVIII, as irmandades do Rosário dos Pretos estavam espalhadas por todo o arcebispado da Bahia, nas cidades e vilas do Recôncavo, avançando sobre o sertão de Baixo e atingindo até a Capitania de Sergipe D'el Rei (p. 172). Na maioria dos casos, explica ela, os negros da nação angola dominavam os cargos diretivos, apesar do número considerável de irmãos de outras origens étnicas, pois não havia impedimento para o ingresso de 
negros de outras nações nestas irmandades.

A constatação empírica da convivência entre africanos de nações diferentes nessas associações religiosas indica que a suposta homogeneidade étnica na composição das irmandades de cativos e forros é mais fantasiosa do que real. Pressupõe, aliás, uma rigidez étnica desses grupos que, no entendimento da pesquisadora, foi um grande equívoco da análise de Arthur Ramos e de seus discípulos. Primeiro, porque o antropólogo alagoano e seus seguidores consideraram a identidade desses grupos na América como uma transposição direta da matriz africana, suprimindo a história; depois, porque as denominações recebidas pelos grupos africanos não eram homogêneas, embora tenham sido, pouco a pouco, incorporadas como realidades sociais (p. 154).

As festas e cerimônias religiosas organizadas pelas irmandades tiveram, certamente, um papel importante na construção das identidades social e religiosa das nações africanas, tanto em Portugal como no Brasil colonial. Assim como a devoção à santa, a eleição de reis e rainhas negros fortalecia os elos de coesão do grupo. A despeito das variantes regionais, explica Reginaldo, os reinados remetiam ao processo de conversão no reino do Congo no século XVI e davam mostras "do vigor das tradições centro-africanas lembradas e recriadas nas Américas" (p. 226). Portanto, longe de representar a vitória da religião e dos costumes europeus, "o Rei do Congo representava o triunfo das estratégias contínuas para preservar as ligações com a África". ${ }^{3}$

Aos dias festivos do calendário da irmandade sucediam-se os dias comuns, às vezes pontuados por conflitos. O rei eleito muitas vezes atuava como um mediador entre os irmãos da confraria e as autoridades civis e eclesiásticas. Mas houve casos, revela a autora, em que os confrades recorreram à intervenção do soberano português para deter a ganância de vigários e capelães. Exasperados pela falta das côngruas, os sacerdotes abusavam na cobrança das taxas pagas por confissão, comunhão, extrema-unção e outros sacramentos, sobrecarregando os gastos dos irmãos do Rosário das Portas do Carmo, por exemplo. Como é de se presumir, o recurso à autoridade régia para resolver pendengas desta natureza irritava as autoridades eclesiásticas. Em 1750, o arcebispo da Bahia chamou os irmãos daquela mesma irmandade de "soberbos, presunçosos e altivos” (p. 239).

Os adjetivos empregados pelo arcebispo para descrever os irmãos pretos do Rosário contrariam o estereótipo criado sobre os negros da nação

Elizabeth Kiddy apud Reginaldo. Os rosários, p. 226. 
angola, em geral tidos como dóceis e flexíveis. Lembra Reginaldo, no quarto capítulo, que a origem desta imagem está diretamente ligada à propaganda dos mercadores de escravos, que se viram prejudicados quando o tráfico da Costa da Mina para a Bahia, no século XVIII, valorizou outros grupos étnicos em detrimento dos bantos. Para avolumar os negócios e enfrentar a concorrência, os traficantes passaram a ressaltar a cordialidade e a boa-vontade dos bantos para aprender o idioma português e a religião católica. Segundo a autora, a estratégia comercial surtiu os efeitos esperados. No século XIX, os senhores de escravos do Rio de Janeiro tinham nítida preferência pelos angolas.

A consagração deste estereótipo deu-se, no entanto, com a chancela do discurso científico, que assumiu o estatuto de "verdade" em fins do Oitocentos. Em Os africanos no Brasil, escrito no início do século $\mathrm{XX}$, mas só publicado em 1932, Nina Rodrigues descreveu os bantos como "degredados, brutais, selvagens", e os nagôs e jejês, como grupos dignos de admiração, apesar de revoltosos e perigosos. Essa visão hierarquizada e evolucionista das culturas africanas influenciou diretamente a produção científica nas décadas seguintes, que insistiu na hegemonia dos negros de origem nagô na formação da religiosidade baiana.

Para desconstruir essa idéia, Re- ginaldo pondera que as pesquisas sobre o tráfico negreiro que apontaram para um maior número de escravos vindos da Costa da Mina, na verdade, só levaram em conta a cidade de Salvador, esquecendo a região do Recôncavo, onde os escravos centroafricanos continuaram sendo usados como mão-de-obra nas plantações fumageiras e açucareiras, pelo menos, até o final do século XVIII.

Por fim, para reforçar a influência das irmandades do Rosário na vida religiosa da colônia, Lucilene Reginaldo analisa, no último capítulo, o funcionamento da Irmandade do Rosário das Portas do Carmo, seu papel como "canal de expressão e integração da população negra no período colonial" (p. 345), advogando suas causas e protegendo seus interesses. Demonstra, assim, que a irmandade negra mais importante de Salvador teve enorme importância na formação do afro-catolicismo baiano, dando ampla visibilidade a um grupo de africanos outrora desprezado pela historiografia da escravidão na Bahia.

Os rosários dos angolas é, por tudo que se disse, um livro importante! Se lhe cabe algum reparo, está circunscrito à ausência de alguma reflexão sobre a história da devoção ao Rosário e do culto mariano no circuito mais amplo da religiosidade popular à época moderna. Importa, no entanto, sublinhar que a autora investe contra os mitos criados pela antro- 
pologia do passado sem, no entanto, reproduzir às avessas a disputa entre bantuístas e nagocêntricos. Vale destacar que demonstra, com enorme competência, como e porque as irmandades foram organismos fundamentais para a construção da identidade social de africanos nas sociedades do império ultramarino português.

Georgina Silva dos Santos Universidade Federal Fluminense 